\title{
USE OF PICTURE AND PICTURE MODEL BASED ON MULTIMEDIA WITH INTERNALIZE CHARACTER EDUCATION ON LANGUAGE CIVILIZED EDUCATIONAL LEARNING
}

\author{
Dewi Afriany Susanti
}

\section{Universitas Quality Medan}

dewigtgs@gmail.com

\begin{abstract}
The research conducted is Classroom Action Research by using Picture and picture model based on multimedia by internalizing character education on civiv education Subject, State IV State Elementary Matter Material 040448 Kabanjahe Lesson Year 2016/2017.The location of this research is SD Negeri 040448 Kabanjahe. The subjects in this study were third grade students of SD Negeri 048232 Kabanjahe which amounted to 49 students and as an object is the improvement of learning on the material of State Coat by using Picture and picture model based on multimedia.Data Collection Techniques are: Observation Sheet Teachers and Observation Sheets of student activities. Data analysis techniques used were observation and test sheets.Based on the research that has been done then the implementation of learning activities of teachers $80 \%$ (good category), the implementation of learning activities 87 students (good category), and student learning outcomes $85 \%$ classically, and the average value 82 .From the results of this study can be concluded that the implementation of learning included into both categories, and student learning outcomes have been increased and completed in a classical manner using the Picture and picture model based on multimedia to Improve Student Results on civiv education Subjects, State IV State Elementary School 040448 Kabanjahe Lesson Year 2016/2017.
\end{abstract}

Keywords: Picture and Picture Model, Multimedia Based, Character Education Internalization, Civic Education

\section{INTRODUCTION}

Education has a very important role in human life. Education is a process of changing one's attitude in the long run. Education is a way to improve the quality of human resources (HR). According to the Law of the Republic of Indonesia No.12 of 2012, education is a conscious and planned effort to create an atmosphere of learning and learning so that learners are actively developing their potential to have religious spiritual power, self-control, personality, intelligence and noble character. Civic education is a subject that is used as a vehicle to develop and preserve the noble and moral values rooted in Indonesian culture. This noble moral value embodied in the form of daily life behavior of students, both as individuals and as social beings in the community, and creatures of God Almighty. The scope of Citizenship Education includes: Pancasila, Nationalism (Nation and national identity), State, Citizenship, Constitution, Good Govermance, Government and Government, Civil-Military Relations, Religion and State Relations, Civil Society, Democracy and Human Rights (Sofhian, 2011: 10). 
The goal of Citizenship Education is to shape the character of a good citizen. In addition, the need for Civics to be taught in primary schools is that students are able to understand and exercise the right and obligation to become intelligent, skilled and characterized Indonesian citizens in accordance with Pancasila and the 1945 Constitution, as well as to understand the values of discipline, honesty, and good attitude against fellow human beings.

To improve students' learning ability and to overcome difficulties faced by students, the researcher applied Multimedia Picture and Picture Model By Internalizing Character Education to Increase Activities and Learning Outcomes of Elementary Students on Citizenship Education Subject. is a series of teaching material delivery by showing concrete images with multimedia point powered to students so that students can understand clearly about the essential meaning of teaching materials that are delivered to students who didalmnya contained the expected character education.

\section{Learning}

Learning is one form of behavior that is very important for human survival. Learn to help humans adjust (adaptation) with the environment. With the human learning process can survive. Learning is the process of changing human behavior. Below are some experts opinions about learning. Learning is one form of behavior that is very important for human survival. Learn to help humans adjust (adaptation) with the environment. With the human learning process can survive. Learning is the process of changing human behavior. R. Gagne in Ahmad Susanto (2014: 1), states: Learning can be defined as a process by which an organism changes its behavior as a result of experience. Learning and teaching are two concepts that can not be separated from one another. These two concepts become integrated in one activity where reaction occurs between teacher and student, as well as students with students at the time of learning. Herman Hudojo in Asep jihan and Abdul Haris (2013: 3) states: Learning is an activity for everyone, knowledge of skills, passion and attitude of a person is formed, modified and developed due to learning. Therefore one is called learning, if it can be assumed in a person to be a process of activity resulting in a change of behavior. Snerner in Dimyati and Mudjiono (2013: 9) states: Learning is a behavior. At the time people learn, the response becomes better. Conversely, then he did not learn then the response decreased. In learning, the following findings are found: (i) chance of occurrence of events which elicits a learners response, (ii) the learner's response, (iii) the corroborating consequences of the response. Reinforcement occurs in the stimulus that corroborates the 
consequences. From some of the opinions of the experts above can be interpreted Learning is the process of one's efforts to improve the cognitive, affective and psychomotor skills acquired through experience and aims to change the personality becomes more established.

\section{Learning Model Picture And Picture}

Picture and Picture Learning Model is a model where teachers use tools or picture media to explain a material or facilitate students to actively learn. By using the tools or media images, it is expected that teaching and learning conditions can be fun and students are able to follow the lesson with focus, and messages delivered by teachers can be accepted and pervasive in the heart, and can be remembered by students.

According to Istarani (2012: 12) Picture and Picture is a series of teaching material delivery by showing concrete images to students, so that students can understand clearly about the essential meaning of the teaching materials presented to him. Thus, the main ingredients of using the Picture and Picture Model are the drawings that concern the learning materials. With no drawing, it is impossible to do the teaching and learning process by using Model Picture and Picutre. According to Hamdani (2011: 89) "Picture and Picture Model is a learning method that uses images that are paired or sorted into a logical sequence". From the opinion of the experts above can be concluded that the Picture and Picture Model is a learning model that the delivery of material by using the pictures and sorted into a logical sequence and have the right argument.

\section{Media}

Media is any form of intermediary used to convey an information or message. The word media comes from the latin medium which is literally 'middle', 'intermediate', or 'observer'. Or in other words the media is an intermediary. According to Arsyad (2013:4) "Media is a tool that is physically used to convey the content of teaching materials, which consists of books, tape recorders, tapes, video cameras, video recorders, films, slides, photographs, pictures, graphics, television and computers ". Furthermore, according to Fathurrohman and Sobry (2007: 65) "Media is a tool used to distribute messages or information from the sender to the recipient of the message". From the opinion of experts above can be concluded that Media is a tool used by educators who used to mnyampaikan teaching materials to learners, so that learners can easily understand the teaching materials presented to him. 
The image media is a visual medium that can be seen only. Media images is the most commonly used learning media, in the form of images relating to teaching materials that serve to convey messages from teacher to student. According to Arsyad (2013: 102) "Media Image is the visualization of messages, information or concepts to be conveyed to students can be developed in various forms, such as photographs, drawings, lines, graphics, charts and a combination of two or more forms". : 262) "Media Image is a two-dimensional visual representation that utilizes the drawing design as a means of consideration about everyday life, such as concerning human, events, objects, places and so on." From the opinion of the experts above can be drawn conclusion that Media Image is visible visual media presented to learners relating to teaching materials delivered to him, so as to motivate, encourage, and attract the attention of learners in the learning process.

\section{Model Picture And Picture}

Model Picture and Picture has steps in making it, this matter put forward by Istarani (2012:

7). Step by step Model Picture and Picture

a. The teacher conveys the competence to be achieved.

b. Present the material as an introduction.

c. Teacher shows / shows pictures of activities related to the material.

d. Teachers appoint / invite students alternately to install / sort pictures into a logical sequence.

e. Master asks the reason for the sequence of images.

f. From the reason / sequence of images the teacher starts to instill the concept / material in accordance with the competence to be achieved.

g. Conclusion / summary.

\section{Multimedia}

In the current era of globalization, multimedia is also needed in teaching and learning activities to attract students' attention and make innovations in learning. Therefore, to create a class situation that attracts the merging of the picture and picture model of multimedia-based is very helpful to the teacher in transferring his knowledge to students to facilitate students' understanding of Multimedia lessons is the use of computers to present and combine text, sound, images, animation and video with tools aids (tools) and connections (links) so that 
users can navigate, interacted work and communicate (Hofstetter 2001) as a tool for presentation assistance.

To produce a good and significant multimedia required elements that have the ability to convey an information. The multimedia elements include:

a. Text

The text is usually generated by a word processing program and is the primary information in most multimedia applications, namely the menus, navigation systems and programs themselves. The text is explicit and accurate. Vaughan $(1993, \mathrm{p} 12)$ argues that texts can provide many meanings for expressing what is meant to be so important in the delivery of information to be able to display an app that is appealing, the balance of text usage on the screen needs to be taken into account.

b. Animation

Animation is a moving image. Animation can be generated by displaying picture frames quickly to produce movement effects. With animation, we can present a visual concept which, if described in other ways, will be much more difficult. Animations can also be interactive.

c. Graffic

Graphics are especially useful to illustrate something or compare information. Graphs can be curves, photos, scanners and other images either two-dimensional or threedimensional.

d. Image

The image is an object that can be displayed in graphical form (non-text) or a codeshaped concept that has no relation with time (Andleigh and Thakrar, 1996, p39).

e. Audio

According to Vaughan (1993, p37), sound is the most sensational multimedia element. The integration of audio or sound into multimedia applications can provide information that other media can't provide. There is information that is impossible or very difficult to explain without voice assistance.

\section{Character Education}

Character is the values that are imprinted in the self through education, parenting, experimentation, sacrifice, and environmental influences so that the intrinsic value that underlies the attitude and behavior of a person. Character does not come alone but must be 
formed, developed and built consciously and deliberately. According to the Minister of National Education (2011: 8), there are nine pillars of character, namely:

a. The character of God's love and all of His creation.

b. Independence and responsibility.

c. Honesty / trust and diplomatic.

d. Respectful and polite.

e. Generous and helpful-help and mutual cooperation / cooperation.

f. Confident and hardworking.

g. Leadership and justice.

h. Good and humble.

i. Character of tolerance, peace and unity.

Zainal Aqib (2011: 38), argued that character education is the overall relational dynamics between individuals with various dimensions, both from within and from outside himself. In order for the person to be more able to live his freedom so he can be more responsible for the growth of himself as a person and the development of others in their lives. In short, character education bias is defined as a social aid so that the individual can grow in living his freedom in living with others in the world. According to the Ministry of National Education (2011: 21), in practice character education is a system of planting the values of the character in the school community that includes the components of knowledge, awareness or willingness, and actions to implement those values, both against God Almighty (YME). Self, fellow, environment, and, nationality to become human beings kamil us. Character education is character education plus, which involves aspects of knowledge (cognitive), feeling (feeling), and action (action). According to Thomas Lickona (in Kemendiknas 2011: 7), without these three aspects, then education will not be effective. So, it can be concluded that character education is education to form values, moral education, moral education, character education, or moral education that aimed at developing the ability of learners to give good decisions, and realize the goodness of good in everyday life.

\section{Civic Education}

The Nature of Citizenship Education is a conscious and planned effort to educate the nation's life for citizens by fostering the nation's identity and morals. Pancasila and Citizenship Education are subjects focusing on religious, socio-cultural, linguistic, age and

18 | Use of Picture and Picture Model Based on Multimedia with Internalize Character Education on Language Civilized Educational Learning 
ethnic formation, to be intelligent, skilled, and characterized citizens mandated by Pancasila. The purpose of Civics subject is as follows:

a. Think critically, rationally, and creatively in response to citizenship issues.

b. Participate in a responsible and responsible way and act intelligently in the activities of society, nation, and state.

c. Growing positively and democratically to establish themselves based on the characters of Indonesian society in order to live together with other nations.

d. The goal of Citizenship Education is to shape the character of a good citizen. In addition, the need for Civics to be taught in primary schools is that students are able to understand and exercise the right and obligation to become intelligent, skilled and characterized Indonesian citizens in accordance with Pancasila and the 1945 Constitution, as well as to understand the values of discipline, honesty, and good attitude against fellow human beings.

The material taken from the Civics subject of the subject of the State Symbol of Indonesia is Pancasila. Pancasila has a symbol on every silanya and also has meaning and meaning. State symbol of a gold-colored Garuda Birds shrouded shields in which pictured symbols Pancasila, and gripped a piece of white ribbon that reads "BHINNEKA TUNGGAL IKA". In accordance with the design, the symbol is officially named Garuda Pancasila.Pancasila is the basic ideology for the state of Indonesia. The name is made up of two Sanskrit words: five means five and sila means principle or principle. Pancasila is the formulation and guidance of the life of nation and state for all the people of Indonesia. Garuda Pancasila consists of three main components, namely Garuda Bird, shield.

\section{METHODS}

Type of research conducted is research Action Class (PTK). The subject in Classroom Action Research (PTK) is a fourth grader SDN 048232 Kabanjahe Lesson Year 2015/2016. The object of this study is the result of student learning in the lesson of Civics using Picture and Picture Model Based Multimedia by Internalizing Character Education on the subject of Civics subject of the State Symbol Indonesia.

Data Collection Tools are:

a. Observation Sheets (Teachers and students)

b. Test 


\section{Data Analysis Techniques are:}

1. Observasi

Observation is conducted to determine the suitability of the action done with the plan that has been prepared, so it can be seen whether the implementation of the action carried out to produce changes in accordance with the desired.

To analyze the result of observation to teacher and student determined by formula:

a. Master Activity Assessment

To know the implementation of learning teacher activity used the formula:

$$
\mathrm{HP}=\frac{\text { Number of Observation } \text { Results }}{\text { Number of Observation } \text { Points }} \quad \text { (Piet A.Sahertian, 2013:61) }
$$

Table 1

Assessment Criteria in the Implementation of Learning Teacher Activity (Piet A.Sahertian, 2013: 61)

\begin{tabular}{ll}
\hline \multicolumn{1}{c}{ Assessment Criteria } & \multicolumn{1}{c}{ Information } \\
\hline $\mathrm{A}=81-100 \%$ & Very well \\
\hline $\mathrm{B}=61-80 \%$ & Good \\
\hline $\mathrm{C}=41-60 \%$ & Enough \\
\hline $\mathrm{D}=21-40 \%$ & Less \\
\hline $\mathrm{E}=0-20 \%$ & Very less
\end{tabular}

b. Assessment of Student Activities

To know the implementation of student activity learning used the formula: Value of Students

$=\frac{\text { An Acquisition Score }}{\text { Maximum Score }} \times 100$

(Adoption of Asep Jihad and Abdul Haris, 2012: 130) 
Table 2

Assessment Criteria in the Implementation of Learning

Student Activity (Asep Jihad, 2012: 130)

\begin{tabular}{ll}
\hline Assessment criteria & Information \\
\hline $1=10-29$ & Very less \\
\hline $2=30-49$ & Less \\
\hline $3=50-69$ & Enough \\
\hline $4=70-89$ & Good \\
\hline $5=90-100$ & Very good
\end{tabular}

\section{Learning Result}

a. Determining Individual Student Assessment by the formula:

$$
K B=\frac{T}{T t} X 100 \%(\text { Trianto, 2010:241) (3) }
$$

Information :

$\mathrm{KB}=$ Mastery learning

$\mathrm{T} \quad=$ Number of Scores Students Gained

$\mathrm{Tt}=$ Total Score Total

b. Determining Student's Students' Satisfaction With the formula:

$$
\sum \text { students complete learning }
$$

$$
\begin{aligned}
& \mathrm{P}=\longrightarrow 100 \% \\
& \sum \text { student } \\
& \text { (Zainal Aqib,dkk,2010:41) }
\end{aligned}
$$

c. Determining the average value of a class by the formula:

$\bar{x}=\frac{\sum f i . x i}{\sum f i} \operatorname{Sudjana}(2005: 67)$

Information :

$\bar{X} \quad=$ Avarage Value

$\sum f i . x i=$ the sum of all student grades

$\sum f i=$ the number of students 
By using Model Picture And Picture Based Multimedia By Internalizing Character Education on Civic Subjects The subject of State Coat of Arms in Class IV SD Negeri 040448 Kabanjahe Lesson Year 2016/2017 can increase student learning outcomes and complete the classical and implementation of good categorized learning

\section{RESULTS AND DISCUSSION}

Based on the analysis of data on cycles I and II then the important points that need to be studied are as follows.

1. Pelaksanaan Pembelajaran

a. Based on the results of research on the first cycle is known implementation of learning activities of teachers $53.33 \%$ (sufficient criteria) because it has not met the standard provisions of the implementation of learning is at least $75 \%$ (good criteria). While the activity of student 58,33 (criteria enough) because not yet fulfill standard of instruction implementation requirement that is, at least 75 (good criterion) by applying Picture and Picture Model Based Multimedia by Internalizing Character Education at Cnn subject of State Coat Subject in Class IV SD Negeri 040448 Kabanjahe Lesson Year 2016/2017.

b. Based on the result of the research in cycle II, it can be seen that the implementation of learning activity of teacher is $77,83 \%$ (good criterion because it has fulfill the standard of instruction implementation that is minimum $75 \%$ (good criterion) and student activity 86,66 (good criterion) the provisions of the implementation of learning is 75 (good criteria) by applying Model Picture and Picture Model Based Multimedia By Internalizing Character Education on the Subject of Civics Symbol of the State in Class IV Elementary School 040448 Kabanjahe Lesson Year 2016/2017.

c. Thus, the implementation of learning by applying the Picture and Picture Model Based Multimedia By Internalizing Character Education on the Subject of Civics The subject of the State Coat of Arms in Class IV SD Negeri 040448 Kabanjahe Lesson Year 2016/2017 is classified as good Criteria.

1. Learning Result

a. Cycle I of 49 students of 30 students complete class (61.22\%) students and from 49 students the number of students who do not complete 19 (38,78\%) by Applying Multimedia Picture And Picture Model Model By Internalizing Character Education at Civic Subjects Subjects of State Coat of Arms in Class IV Elementary School 040448 Kabanjahe Lesson Year 2016/2017. not yet completed classically because where a class 
is said to complete the classical learning if in the class there are $85 \%$ of students who have completed study while the average obtained is 69.79 .

b. Cycle II of 49 students who complete classically $45(91,83 \%)$ students and from 49 students the number of students who are not complete $4(8.17 \%)$ by applying Multimedia Model Picture and Picture Model By Internalizing Character Education at Civic Subjects Subjects of State Coat of Arms in Class IV Elementary School 040448 Kabanjahe Lesson Year 2016/2017. because where a class is said to complete the classical learning if in the class there are $85 \%$ of students who have completed study while the average obtained is 85.30 .

Thus the results of student learning by applying Model Picture and Picture Model Based Multimedia By Internalizing Character Education on the Subject of Civics The subject of State Coat of Arms in Class IV Elementary School 040448 Kabanjahe Lesson Year 2016/2017 increased and completed in a classical.

\section{CONCLUSION}

The conclusion in this research are:

1. Implementation of Learning by applying Picture and Picture Model Based Multimedia By Internalizing Character Education at Cnm Lesson already categorized Good.

2. Learning outcomes are increasing by applying Multimedia-Based Picture and Picture Models By Internalizing Character Education on Civic Subjects.

\section{ACKNOWLEDGMENT}

For that writing to thank as much as possible to:

1. Mrs. Prof. Dr. Erna Frida, M. Si as the Rector of the University of Quality.

2. Mr. Drs. Osbeth Sinaga, M.Si as Vice Chancellor of Quality University.

3. Mr. Drs. Heriyanto, M.Pd, as Dean of FKIP University of Quality.

4. Drs. Pandapotan Tambunan, M.Pd, As Head of Teacher Education Program of Elementary School of Quality University.

5. Mr. and Mrs. Lecturer / Teaching Staff at the Faculty of Teacher Training and Education University of Quality.

6. Headmaster of SDN 040448 Kabanjahe.

7. To the big family and To colleagues 


\section{REFERENCES}

Arikunto, Suharsimi, dkk. (2012). Penelitian Tindakan Kelas. Jakarta: Bumi Aksara.

Arsyad. A. (2013). Media pembelajaran. Jakarta: PT Raja Grafindo Persada.

Dimyati dan Mudjiono. (2013). Belajar dan Pembelajaran. Jakarta: PT Rineka Cipta.

Fathurrohman dan M. Sobry Sutikno. (2007). Strategi Belajar Mengajar. Bandung: PT. Refika Aditama.

Fathurrohman, Muhammad. (2015). Model-Model Pembelajaran Inovatif. Jakarta: AR.RUZZ Media.

Hamdani. (2011). Strategi Belajar Mengajar. Bandung: Pustaka Setia.

Hofstetter,Fried T. (2001), Multimedia Literacy. Third Edition. McGraw-Hill International Edition: New York.

Istarani. (2011). 58 Model Pembelajaran Inovatif (Referensi Guru Dalam Menentukan Model Pembelajaran) Medan: Media Pustaka.

Jihad, Asep dan Abdul Haris. (2013). Evaluasi Pembelajaran. Yogyakarta: Multi Pressindo.

Muslich, Masnur. (2011). Melaksanakan PTK itu Mudah. Jakarta: PT Bumi Aksara.

Piet A Sahertian. (2010).Konsep Dasar dan Tehnik Supervisi Pendidikan dalam Rangka Pengembangan Sumber Daya Manusia. Jakarta: PT Rineka Cipta.PS.

Purwanto.( 2011). Evaluasi Hasil Belajar. Surakarta: Pustaka Pelajar.

Sekretariat Direktoral Jendral Pendidikan Dasar Kementerian Pendidikan Nasional. (2011). Mencari Karakter Terbaik dari Belajar Sejarah. Jakarta: Kementerian Pendidikan Nasional.

Sekretariat Direktoral Jendral Pendidikan Dasar Kementerian Pendidikan Nasional. 2011.

Pendidikan Karakter dalam Pembelajaran PKn. Jakarta: Kementerian Pendidikan Nasional.

Sofhian,S dn Sahid.A (2011) Pendidikan Kewarganegraan (Civiv Education) Pendidikan politik. Nasionalisme dan Demokrasi. Bandung Fokusmedia.

Trianto. (2011). Mendesain Model Pembelajaran Inovatif Progresif Konsep, Landasan dan Implementasinya pada Kurikulum Tingkat Satuan Pendidikan (KTSP). Jakarta: Kencana Prenada Media Group.

UU No. 12 Tahun 2012 Tentang Sistem Pendidikan Nasional.

Zainal Aqib. (2011). Pendidikan Karakter Membangun Perilaku Positif Anak Bangsa. Bandung: CV. Yrama widya. 